\title{
Determine the effects of drying temperature on the quality change and antioxidant activity characteristics of blueberry
}

\author{
Dong-Sun Shin ${ }^{1}$, Yeon-Mi Yoo ${ }^{2}$, Ha-Yun Kim ${ }^{2}$, Gwi-Jung $\mathrm{Han}^{2 *}$ \\ ${ }^{1}$ Petitami R\&D, Namyangju 12181, Korea \\ ${ }^{2}$ National Academy of Agricultural Science, Rural Development Adminstration, Wanju 55365, Korea
}

\section{건조 온도에 따른 블루베리의 품질변화 및 항산화특성}

\author{
신동선 ${ }^{1} \cdot$ 유선미 ${ }^{2} \cdot$ 김하윤 $^{2} \cdot$ 한귀정 $^{2 *}$ \\ ${ }^{1}$ (주쁘띠아미, ${ }^{2}$ 농촌진흥청 국립농업과학원
}

\begin{abstract}
This study was performed to investigate the effect of drying temperature on the quality characteristics and antioxidant activity of blueberry. Blueberries were dried at different times and temperatures, including $\mathrm{A}\left(40^{\circ} \mathrm{C}, 72 \mathrm{hr}\right), \mathrm{B}$ $\left(40^{\circ} \mathrm{C}, 48 \mathrm{~h}\right.$ and $\left.50^{\circ} \mathrm{C}, 24 \mathrm{hr}\right), \mathrm{C}\left(50^{\circ} \mathrm{C}, 72 \mathrm{hr}\right)$, and $\mathrm{D}\left(60^{\circ} \mathrm{C}, 72 \mathrm{hr}\right)$. The yield and $\mathrm{pH}$ ranges of blueberry were determined to be $17.73 \sim 31.17 \%$ and $3.20 \sim 3.25$, respectively. The yield rate of $A$ treatments, soluble solid of D treatments, was the highest. The yield rate and soluble content was the highest in the treatment of $A$ and $\mathrm{D}$, respectively. The moisture content and water activity were significantly decreased with the increase in drying temperature $(p<0.05)$. The $L$ value of $A$ treatment, and $a$ and $b$ values of $D$ treatment were the greatest. In the analysis of texture analyzer, hardness, springiness, cohesiveness, gummiess and chewiness were significantly increased with the increase in drying temperature $(\mathbf{p}<\mathbf{0 . 0 5})$. In the sensory evaluation of blueberry, the appearance and color were the highest in the $A$ treatment. The moisture, texture and taste was highest in the $B$ treatment. The overall acceptability was in the order of B $>$ A $>$ C $>$ D. The total polyphenol content and DPPH radical-scavenging activity were $9.21 \sim 13.05 \mathrm{mg} / \mathrm{GAEg}$ and $61.90 \sim 81.42 \%$, respectively, which were significantly decreased with the increase in drying temperature $(p<0.05)$. Therefore, the optimum time and temperature for blueberry drying was founded to be $B$ treatment $\left(40^{\circ} \mathrm{C}, 48 \mathrm{hr}\right.$ and $\left.50^{\circ} \mathrm{C}, 24 \mathrm{hr}\right)$ among other treatments.
\end{abstract}

Key words : blueberry, quality change, antioxidant activity

\section{서 론}

블루베리는 진달래(Ericaceae)과 산앵두나무속에 속하 는 관목성 식물로서 주로 북미 지역에 분포되어 있다. 북미 에서는 하이부시 블루베리(Vaccinium corymbosum), 로우 부시 블루베리(Vaccinium myritillus) 및 래빗아이 블루베리 (Vaccinium ashei) 등이 상업적으로 재배되고 있다(1). 블루

*Corresponding author. E-mail : hgiaz@korea.kr Phone : 82-63-238-3561, Fax : 82-63-238-3842

Received 8 June 2015; Revised 13 July 2015; Accepted 15 July 2015.

Copyright (c) The Korean Society of Food Preservation. All rights reserved.
베리는 미국 타임지가 선정한 10대 슈퍼푸드 중 하나로 포함되어 그 가치를 인정받아 오고 있으며(2), 최근 미국 하이부시 블루베리협회에서는 블루베리의 건강기능성을 강조하면서 세계적으로 수요가 급증하고 있다고 하였다 (3). 이와 더불어 국내에서도 블루베리에 대한 소비자의 관심이 높아지고 있으며 재배면적이 2009년 $313 \mathrm{ha}, 2010$ 년 $534 \mathrm{ha}$ 이었다가 2011년 1,082 ha로 수요가 급증하면서 새로 운 소득 작물로서 각광을 받고 있다(4). 블루베리에는 영양 성분이 풍부하고 기능성 물질이 다량 함유되어 있어 항산화 (5) 및 항암효과(6,7)가 높은 것으로 보고되었다. 최근 블루 베리에 대한 연구로는 수확 후 블루베리 냉동전처리를 위한 세척시스템 연구(8), 블루베리의 방사선방호 효과 연구(9), 국내산과 미국산 블루베리의 영양성분 연구(10) 등이 보고 
되고 있으며, 블루베리를 이용한 가공식품개발로는 양갱 (11), 과립(12), 요구르트 드레싱(13), 막걸리(14), 쿠키(15), 잼(16) 등의 연구가 보고되고 있다.

블루베리는 표면의 과피가 약하고 대부분이 수분으로 이루어져 있어 미생물의 생육, 생화학적 변화, 화학적 반응 등 식품변질의 요인과 밀접한 관계에 있으며, 이러한 문제 점을 해결하기 위해서 생과 이외에 냉동과, 건조과가 많이 이용되고 있다. 식품 건조는 수분함량이 많은 식품에서 수 분을 제거하여 미생물 및 효소에 의한 부패나 변질을 방지 하여 저장성을 향상시키고 더불어 새로운 식품개발에 있어 서도 그 이용성이 확대되었다. 식품에 이용되는 건조방법 으로는 천일건조를 비롯하여 열풍 건조가 있으며, 건조제 품의 산업화로 인하여 동결건조, 진공건조, 마이크로파, 원 적외선 및 냉풍건조 등 방법이 다양화되어 이에 따른 여러 가지 제품이 개발되고 있다(17). 건 블루베리 제조기술은 건조방법과 건조온도와 같은 건조조건에 따라 좌우되며 (18) 지금까지 건 블루베리 제조에 관한 연구는 미미한 실정 이다.

또한, 농림수산식품부는 블루베리 산업의 발전일환으로 2010년 사단법인 한국블루베리협회를 설립하여 블루베리 운영하고 있으나 개별농가단위 출하가 대부분으로 이루어 져 시장진출이 어려움을 겪고 있다. 블루베리 국내 생산량 이 많아지고 수입량도 증가하면서 농업인들은 더 품질 좋은 과실을 생산하고 소비를 촉진하기 위해서 가공식품 개발에 박차를 가하고 있는 실정이다.

따라서 본 연구에서는 블루베리의 재배면적과 생산량 증가로 생과 및 냉동과 유통의 한계를 대비해 다양한 가공 식품 기술이 필요하므로 저장성이 높고 보관이 용이하며 부재료를 첨가하지 않는 건 블루베리를 제조기술을 확립하 고자 건조 온도 및 시간을 달리하여 건 블루베리의 품질변 화와 항산화 특성을 조사하였다.

\section{재료 및 방법}

\section{실험 재료}

본 실험에 사용한 블루베리 생과는 2013년 6월 경기도 평택에서 생산된 듀크 품종으로 너비와 높이가 $1.2 \pm 0.1$ $\mathrm{cm} \times 0.7 \pm 0.1 \mathrm{~cm}$ 었으며 중량이 약 $2.0 \pm 0.1 \mathrm{~g}$ 인 것을 제공받 아 실험에 적용하였다. 이때 블루베리 생과의 수분 함량은 $89.54 \pm 0.15 \%, \mathrm{pH}$ 는 $3.17 \pm 0.01$, 가용성 고형분 함량은 $9.26 \pm 0.32^{\circ} \mathrm{Brix}$ 이었다.

\section{건 블루베리 제조}

건 블루베리 제조를 위하여 예비실험으로 동결건조와 열풍건조를 수행하였는데, 동결건조는 건조과정에서 과피 가 갈라지고 과육이 밖으로 돌출됨으로써 상품성이 낮아
건조방법으로 적절하지 못하였다. 열풍건조는 건조 온도를 $50^{\circ} \mathrm{C}$ 와 $70^{\circ} \mathrm{C}$ 로 하여 건조한 결과 건조에 소요되는 시간은 각각 90시간(3 4일)과 20시간(1일)이었으나 상품으로 가능 한 것은 약 $38.26 \%$ 로 낮게 형성되었다. 따라서 건조방법은 열풍건조로 결정하여 건조시간은 72시간(3일) 이내로 품질 이 우수한 상품과 형성율을 높이기 위해 건조온도 및 조건 별 실험을 설계하였다. 즉, 블루베리 생과를 물로 세척한 다음 식품건조기(LD-918B, L'EQUIP, Seoul, Korea)를 이용 하여 각각 건조 온도를 달리하여 $\mathrm{A}\left(40^{\circ} \mathrm{C}, 72\right.$ 시간), $\mathrm{B}\left(40^{\circ} \mathrm{C}\right.$,

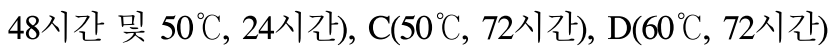
로 하여 열풍건조 한 후 건 블루베리를 제조하였다.

\section{수율, $\mathrm{pH}$, 가용성 고형분 측정}

수율은 블루베리 생과의 무게 중량과 열풍건조 후의 무 게 중량을 측정하여 두 값의 차이를 백분율(\%)로 나타내었 다. $\mathrm{pH}$ 는 건 블루베리의 일정량을 취한 다음 이에 10 배에 해당하는 증류수를 가하고 마쇄한 다음 $\mathrm{pH}$ meter(Orion 3-star, Thermo Scientific, Waltham, MA, USA)로 측정하였 고, 가용성 고형분 함량은 건조 온도별 처리구의 시료와 증류수의 비율을 1:1로하고 homogenizer(ULTRA-TURRAX, T25, IKA Labortechnik Co., Staufen, Germany)를 이용하여 균질하였다. 균질화된 각 시료를 Whatman No. 2 여과지로 여과하여 saccharimeter (PAL-1, ATAGO Co., LTD., Tokyo, Japan)을 이용하여 측정한 후 ${ }^{\circ} \mathrm{Brix}$ 로 나타내었다(18).

\section{수분 및 수분활성도 측정}

건조 온도를 달리하여 제조한 건 블루베리의 수분함량 측정은 각 시료를 일정하게 $2 \mathrm{~g}$ 씩 취하여 상압가열건조법 에 의해 측정하였으며 각 실험은 3 회 반복 측정하여 평균값 과 표준편차로 나타내었다(19). 수분활성도 측정은 건조 블루베리 시료 $1 \mathrm{~g}$ 를 채취하여 수분활성측정기(LabMasteraw, Novasina Co., Lachen, Switzerland)를 이용하여 3회 반 복 측정하여 평균값을 구하였다(19).

\section{색도 측정}

건조 온도를 달리한 건조 블루베리의 색도 측정은 색차 계(Color-Eye 3100, Macbeth, New Windsor, NY, USA)를 이용하여 L값(명도, lightness), $a$ 값(적색도, redness), $b$ 값(황 색도, yellowness)을 5 회 측정한 뒤 평균값을 나타내었으며 표준 백색판(standard plate)의 L값은 97.16 , a 값은 $-0.01, b$ 값 은 0.03 이었다(18).

\section{조직감 측정}

건조 온도를 달리한 건조 블루베리의 조직감 측정은 texture analyser(TA-XT2, Stable Micro System Ltd., Haslemere, UK)를 이용하여 측정하였다. Texture profile analysis(TPA) 방법으로 2nd bite compression test로 10회 
이상 반복 측정한 후 force distance curve로 부터 경도 (hardness), 탄력성(springiness), 응집성(cohesivenss), 점성 (gumminess), 씹힘성(chewiness)을 측정하였으며 측정 조건 은 pre-test speed $3.0 \mathrm{~mm} / \mathrm{s}$, post-test speed $3.0 \mathrm{~mm} / \mathrm{s}$, distance $10 \mathrm{~mm}$ 의 조건으로 직경 $5 \mathrm{~mm}$ 의 cylindrical probe를 사용하 여 10 회 반복 측정하였다.

\section{관능검사}

건조 온도를 달리한 건조 블루베리의 관능검사는 실험목 적과 관능적 평가항목을 잘 인지하도록 반복 훈련시킨 농식 품자원부의 식품을 전공한 연구원 20명을 구성원으로 관능 검사를 실시하였다. 평가항목은 외관(appearance), 색(color), 수분정도(moisture), 조직감(texture), 맛(taste), 전반적 기호 도(overall acceptability)를 9점 기호도법 (1점: '대단히 나쁘 다', 5점: ‘보통이다', 9점: ‘대단히 좋다’)평가하도록 하였 다. 각 시료는 흰색접시에 담아 제시하였으며 전 시료가 다음 시료에 영향을 주지 않도록 각 시료 검사 전에는 반드 시 입가심 물 $\left(40^{\circ} \mathrm{C} \pm 2\right)$ 로 깨끗이 행군 다음 평가하도록 하 였다.

\section{총 폴리페놀 함량 및 항산화 활성}

건조 온도를 달리한 건 블루베리의 항산화 활성을 측정 하기 위한 시료의 추출물 제조는 $75 \%$ ethanol 용매를 추출 용매로 하여 실온에서 24시간 동안 추출한 후 Whatman No. 2(Whatman plc., Kent, UK) 여과지로 여과하여 얻은 여액을 분석용 시료로 사용하였다.

총 폴리페놀 함량은 Folin-Denies법을 이용하여 측정하 였다(20). 각 추출물 시료 $1 \mathrm{mg}$ 을 증류수 $1 \mathrm{~mL}$ 에 녹이고 10 배 희석한 희석액 $2 \mathrm{~mL}$ 에 2 배 희석한 Folin 시약 0.5 $\mathrm{mL}$ 을 첨가하고 혼합한 다음 3 분 동안 방치한 후 $20 \%$ $\mathrm{Na}_{2} \mathrm{CO}_{3} 1 \mathrm{~mL}$ 을 넣고 1 시간 동안 반응 시킨 다음 분광광도 계(JP/ U-2000 spectrophotometer, Hitachi Ltd., Tokyo Japan) 를 사용하여 $725 \mathrm{~nm}$ 에서 흡광도를 측정하였다. 표준물질로 gallic acid를 이용하여 검량선을 작성하고 시료 $1 \mathrm{~g}$ 중의 $\mathrm{mg}$ gallic acid equivalent (GAE, dry basis)로 표시하였다.

$\mathrm{DPPH}$ radical 소거능 측정은 Blois의 방법(21)에 따라 측정하였다. 추출 시료 $2 \mathrm{~mL}$ 과 $1.5 \times 10^{-4} \mathrm{M} \mathrm{DPPH}$ 용액 (Sigma Chemical Co., St. Louis, MO, USA)을 $1 \mathrm{~mL}$ 가하고 암실에서 30 분간 반응 시킨 후 분광광도계(JP/U-2000 spectrophotometer, Hitachi Ltd., Tokyo Japan)를 사용하여 $517 \mathrm{~nm}$ 에서 흡광도를 측정하였다. DPPH radical scavenging $\operatorname{activity}(\%)=100-[(\mathrm{OD}$ of sample/OD of control $) \times 100]$ 에 의 하여 활성도를 산출하였다.

\section{통계처리}

실험에서 얻어진 결과에 대한 통계 분석은 SPSS program(12.0, SPSS Inc., Chicago, IL, USA)을 이용하여 일
원배치 분산분석을 실시하였고, Duncan's multiple range test를 이용하여 집단 간 유의성을 검정하였다( $\mathrm{p}<0.05)$.

\section{결과 및 고찰}

\section{수율, $\mathrm{pH}$, 가용성 고형분 변화}

건조 온도 조건을 달리하여 제조한 건 블루베리의 수율, $\mathrm{pH}$, 가용성 고형분 함량은 Table 1 에서 보는 바와 같다. 먼저 수율을 측정한 결과 17.73 31.17\%의 범위로 확인되었 으며 건조 온도가 낮을수록 유의적으로 높게 나타났다 ( $\mathrm{p}<0.05)$. 한편, 건조온도 조건별로 $\mathrm{pH}$ 를 측정한 결과 $\mathrm{A}(4$ $0^{\circ} \mathrm{C}-72$ 시간) 처리군이 $\mathrm{pH} 3.25$ 로 가장 높았고 나머지 처리 군인 $\mathrm{B}\left(40^{\circ} \mathrm{C}-48\right.$ 시간, $50^{\circ} \mathrm{C}-24$ 시간 $), \mathrm{C}\left(50^{\circ} \mathrm{C}-72\right.$ 시간 $), \mathrm{D}(6$ $0^{\circ} \mathrm{C}-72$ 시간)간의 차이는 없었다. 이는 Park 등(18)의 연구와 비슷한 결과로 건조에 따른 블루베리의 $\mathrm{pH}$ 를 측정한 결과 열풍건조일 경우 $60^{\circ} \mathrm{C}$ 에서 3 일 동안 건조하였을 때 $\mathrm{pH} 2.83$ 이었으며, 건조방법인 동결건조, 감압건조에 따른 $\mathrm{pH}$ 는 차 이가 없었다고 보고하였다. 또한, 가용성 고형분 함량은 건조 온도가 높은 D 처리군이 $21.26^{\circ} \mathrm{Brix}$ 로 가장 높았으며 건조 온도가 낮은 A 처리군이 $19.04^{\circ} \mathrm{Brix}$ 로 가장 낮아 건조 온도가 높을수록 유의적으로 높아지는 것으로 나타났다 (p<0.05). 이러한 고형분 함량의 차이는 건조과정 중에 수분 함량의 차이(22)로 건조방법 및 건조 온도에 따라서도 연관 이 있을 것으로 생각된다.

Table 1. Yield rate, $\mathrm{pH}$ and soluble solid of dried blueberry with different drying temperatures

\begin{tabular}{cccc}
\hline $\begin{array}{c}\text { Drying } \\
\text { condition }^{1)}\end{array}$ & $\begin{array}{c}\text { Yield rate } \\
(\%)\end{array}$ & $\mathrm{pH}$ & $\begin{array}{c}\text { Soluble solid } \\
\left({ }^{\circ} \text { Brix }\right)\end{array}$ \\
\hline A & $31.17 \pm 1.26^{\mathrm{a} 2)}$ & $3.25 \pm 0.01^{\mathrm{a}}$ & $19.04 \pm 0.27^{\mathrm{d}}$ \\
B & $28.48 \pm 1.26^{\mathrm{b}}$ & $3.20 \pm 0.20^{\mathrm{b}}$ & $19.97 \pm 0.17^{\mathrm{c}}$ \\
C & $20.40 \pm 1.26^{\mathrm{c}}$ & $3.21 \pm 0.32^{\mathrm{b}}$ & $20.53 \pm 0.28^{\mathrm{b}}$ \\
D & $17.73 \pm 1.26^{\mathrm{d}}$ & $3.21 \pm 0.28^{\mathrm{b}}$ & $21.26 \pm 1.05^{\mathrm{a}}$ \\
\hline
\end{tabular}

${ }^{1)} \mathrm{A}, 40^{\circ} \mathrm{C}-72 \mathrm{hr} ; \mathrm{B}, 40^{\circ} \mathrm{C}-48 \mathrm{hr}$ and $50^{\circ} \mathrm{C}-24 \mathrm{hr} ; \mathrm{C}, 50^{\circ} \mathrm{C}-72 \mathrm{hr} ; \mathrm{D}, 60^{\circ} \mathrm{C}-72 \mathrm{hr}$. ${ }^{2)}$ Values are mean $\pm \mathrm{SD}(\mathrm{n}=3)$. Means with different superscripts within a column differ significantly $(\mathrm{p}<0.05)$.

\section{수분 및 수분활성도 변화}

건 블루베리의 적당한 수분함량은 식감이나 제품의 품질 정도를 좌우하는 중요한 지표가 된다. 건조 온도에 따른 건 블루베리의 수분함량의 변화를 측정한 결과는 Table 2에 서 나타내었다. 즉, 건조 온도가 높을수록 수분함량은 낮아 지는 경향으로 A, B, C 및 D가 각각 $48.40 \%, 38.23 \%, 31.17 \%$ 및 $16.17 \%$ 로 나타났다. 앞의 결과와 비교해보면 수분함량 이 높을수록 가용성 고형분 함량은 낮아지고 수분함량이 낮을수록 가용성 고형분 함량이 높아지는 경향을 보여 이들 의 연관성을 확인할 수 있었다. 또한, 이러한 수분함량의 
차이는 건조 온도 및 건조시간에 따른 블루베리의 수분 증발현상에 의한 것으로 생각된다. Park 등(18)의 연구에서 블루베리를 $60^{\circ} \mathrm{C}$ 에서 3 일 열풍건조 했을 경우 $13.10 \%$ 로 본 실험의 D 처리군 $16.17 \%$ 와 다소 차이를 보인 것은 블루 베리의 종류 및 실험조건이 다소 다르기 때문으로 생각된 다. 한편, 국내산 베리류 생과의 수분함량을 측정한 결과 모든 품종이 $80 \%$ 이상의 수분함량을 함유하고 있다고 보고 하기도 하였다(23).

수분활성도는 미생물의 생육과 직접적인 연관이 있는 중요한 인자로 수분활성도가 높을수록 미생물의 번식이 빠르게 진행된다. 건조 온도에 따른 건 블루베리의 수분활 성도의 변화는 Table 2에서 보는 바와 같이 $\mathrm{A}, \mathrm{B}, \mathrm{C}$ 및 $\mathrm{D}$ 처리구가 각각 $0.77 \%, 0.71 \%, 0.70 \%$ 및 $0.68 \%$ 로 나타내 었다. 즉, $\mathrm{A}$ 처리군이 $0.77 \%$ 로 가장 높게 나타났으며 $\mathrm{D}$ 처리군이 $0.68 \%$ 로 가장 낮은 값을 나타내어 저장성은 유리 하겠지만 외관상 품질이 우수한 상품과 형성율이 적어 6 $0^{\circ} \mathrm{C}$ 에서 72 시간 건조하는 것은 적당하지 않는 것으로 생각 된다.

Table 2. Moisture content and water activity of dried blueberry with different drying temperatures

\begin{tabular}{ccc}
\hline $\begin{array}{c}\text { Drying } \\
\text { condition }\end{array}$ & $\begin{array}{c}\text { Moisture content } \\
(\%)\end{array}$ & $\begin{array}{c}\text { Water activity } \\
(\%)\end{array}$ \\
\hline A & $48.41 \pm 0.41^{\mathrm{a} 2)}$ & $0.77 \pm 0.01^{\mathrm{a}}$ \\
B & $38.23 \pm 0.20^{\mathrm{b}}$ & $0.71 \pm 0.00^{\mathrm{b}}$ \\
C & $31.17 \pm 0.32^{\mathrm{c}}$ & $0.70 \pm 0.01^{\mathrm{b}}$ \\
D & $16.48 \pm 0.28^{\mathrm{d}}$ & $0.68 \pm 0.01^{\mathrm{c}}$ \\
\hline
\end{tabular}

${ }^{1)} \mathrm{A}, 40^{\circ} \mathrm{C}-72 \mathrm{hr} ; \mathrm{B}, 40^{\circ} \mathrm{C}-48 \mathrm{hr}$ and $50^{\circ} \mathrm{C}-24 \mathrm{hr} ; \mathrm{C}, 50^{\circ} \mathrm{C}-72 \mathrm{hr}$; D, $60^{\circ} \mathrm{C}-72 \mathrm{hr}$. ${ }^{2)}$ Values are mean $\pm \mathrm{SD}(\mathrm{n}=3)$. Means with different superscripts within a column differ significantly $(\mathrm{p}<0.05)$.

\section{색도 변화}

건조 온도에 따른 건 블루베리의 색도를 측정한 결과 $\mathrm{L}$ 값은 건조 온도가 낮은 $\mathrm{A}$ 처리구가 높게 나타난 반면 $\mathrm{a}$ 값 및 $\mathrm{b}$ 값의 경우는 건조 온도가 높은 $\mathrm{D}$ 처리구가 높게 나타났다(Table 3). 건조된 건 블루베리의 색도는 건조 온도 가 높을수록 건조는 빨리 되었지만 육안으로 보았을 때 과피의 색이 주황색으로 변하여 상품으로 적절하지 않았고 건조 온도가 낮을수록 색은 더 밝고 자주색이 더 선명하여 색의 변화가 적었다. 즉, $\mathrm{A}$ 와 $\mathrm{B}$ 처리군의 경우 블루베리 고유의 색이 유지되었지만 $\mathrm{A}$ 처리군은 건조가 잘 이루어지 지 않아 상품으로 가능한 것이 약 $46 \%$ 로 낮았고 B처리군은 상품으로 가능한 것이 약 $93 \%$ 이상으로 높았다. 따라서 $\mathrm{A}$ 처리군은 건조 소요시간을 더 늘려 건조가 이루어져야 하며 $\mathrm{B}$ 처리군 처럼 $40^{\circ} \mathrm{C}$ 에서 48 시간 건조 후 다시 $50^{\circ} \mathrm{C}$ 에서 24 시간 건조하는 것이 바람직 할 것으로 생각된다. 한편, 열풍건조로 $60^{\circ} \mathrm{C}$ 에서 3 일 동안 건조한 블루베리의 색도를 측정한 결과 $\mathrm{L}$ 값이 $24.17, \mathrm{a}$ 값이 $8.21, \mathrm{~b}$ 값이 7.64 이었다는
연구보고가 있었으며(18), Yook 등의 연구(24)에서는 열풍 건조한 포도의 색도를 측정한 결과 $\mathrm{L}$ 값이 30.46 , a값이 $10.89, \mathrm{~b}$ 값이 8.78 으로 본 실험의 결과와 다소 차이를 보였 다. 이는 건 블루베리 제조에서 건조기에 의한 차이 때문인 것으로 생각된다.

Table 3. Color value of dried blueberry with different drying temperatures

\begin{tabular}{cccc}
\hline \multirow{2}{*}{$\begin{array}{c}\text { Drying } \\
\text { condition }\end{array}$} & \multicolumn{3}{c}{ Color value } \\
\cline { 2 - 4 } & $\mathrm{L}$ & $\mathrm{a}$ & $\mathrm{b}$ \\
\hline $\mathrm{A}$ & $24.48 \pm 0.56^{\mathrm{a} 2)}$ & $0.30 \pm 0.02^{\mathrm{c}}$ & $-4.06 \pm 0.09^{\mathrm{c}}$ \\
$\mathrm{B}$ & $23.91 \pm 0.06^{\mathrm{b}}$ & $0.37 \pm 0.01^{\mathrm{c}}$ & $-4.17 \pm 0.01^{\mathrm{d}}$ \\
$\mathrm{C}$ & $23.00 \pm 0.01^{\mathrm{c}}$ & $1.46 \pm 0.02^{\mathrm{b}}$ & $-3.50 \pm 0.01^{\mathrm{b}}$ \\
$\mathrm{D}$ & $22.31 \pm 0.0^{\mathrm{cd}}$ & $4.62 \pm 1.3^{\mathrm{a}}$ & $-1.84 \pm 1.0^{\mathrm{a}}$ \\
\hline
\end{tabular}

${ }^{11} \mathrm{~A}, 40^{\circ} \mathrm{C}-72 \mathrm{hr} ; \mathrm{B}, 40^{\circ} \mathrm{C}-48 \mathrm{hr}$ and $50^{\circ} \mathrm{C}-24 \mathrm{hr} ; \mathrm{C}, 50^{\circ} \mathrm{C}-72 \mathrm{hr}$, D, $60^{\circ} \mathrm{C}-72 \mathrm{hr}$. ${ }^{2)}$ Values are mean $\pm \mathrm{SD}(\mathrm{n}=5)$. Means with different superscripts within a column differ significantly $(\mathrm{p}<0.05)$.

\section{조직감 변화}

건조 온도에 따른 건 블루베리의 조직감을 측정한 결과 는 Table 4에서 보는 바와 같다. 경도(hardness)은 수분함량 이 가장 많은 $\mathrm{A}$ 처리군이 $3,008.00$ 으로 가장 낮았고 $\mathrm{D}$ 처리 군이 9,797.64로 가장 단단한 것으로 건조 온도가 높을수록 높은 값을 나타내었다( $<<0.05)$. 탄력성(springiness)과 응집 성(cohesiveness)은 비슷한 경향으로 건조 온도가 높을수록 약간 증가하는 경향이었지만 유의적인 차이는 없었다 $(\mathrm{p}<0.05)$. 점성 (gumminess)과 씹힘성(chewiness)도 건조 온 도가 높을수록 높은 값을 나타내었으며 유의적으로 처리군 간의 차이가 나타났다( $\mathrm{p}<0.05)$. 이와 같은 조직감의 차이는 열풍 건조과정 중의 온도 및 시간 등의 조건에 따라 나타난 수분함량의 차이로 상관관계가 있을 것으로 생각된다.

\section{관능적 특성}

건조 온도를 달리하여 건조한 건 블루베리의 관능검사를 실시한 결과를 Table 5에 나타내었다. 외관은 $\mathrm{A}$ 처리군이 7.0점으로 가장 높았으며 $\mathrm{D}$ 처리군이 4.1점으로 낮게 평가 되었으며 건조 온도가 낮을수록 외관에 대한 기호도가 유의 적으로 높게 평가 되었다( $\mathrm{p}<0.05)$. 색의 경우 4.6 7.0점으로 외관과 비슷한 경향으로 평가되어 건조 온도가 낮을수록 블루베리 고유의 색을 유지하고 있어 높은 점수를 받았다 $(\mathrm{p}<0.05)$. 수분정도, 조직감 및 맛에 대한 평가는 모든 평가 항목에서 $\mathrm{B}\left(40^{\circ} \mathrm{C}, 48\right.$ 시간 및 $50^{\circ} \mathrm{C}, 24$ 시간 $)$ 처리군이 가장 높게 평가되었으며 그 다음으로 $\mathrm{A}>\mathrm{C}>\mathrm{D}$ 순으로 평가되었 다. 전반적인 기호도는 $\mathrm{A}, \mathrm{B}, \mathrm{C}, \mathrm{D}$ 처리군이 각각 7.1점, 7.6점, 6.0점 및 3.6점으로 $\mathrm{B}$ 처리군이 가장 높은 점수로 평가되어 선호도가 가장 높았으나, $\mathrm{D}$ 처리군은 가장 점수가 낮아 유의적으로 선호도가 낮게 평가되었다( $\mathrm{p}<0.05)$. Choi 
등은 건조 과일을 가공제품에 적용하고자 할 때에는 저장성 및 맛의 기호도를 증진시키기 위해서 당절임에 의한 삼투압 건조를 이용한 후 열풍건조하는 방법이 적합하다고 보고되 기도 하였다(25). 따라서 건 블루베리 제조에 적당한 가공조 건은 가장 선호도가 좋았던 $\mathrm{B}$ 처리군으로 열풍건조 온도를 $40^{\circ} \mathrm{C}$ 로 하여 48 시간 건조 후 온도를 $50^{\circ} \mathrm{C}$ 로 높여 24 시간 동안 건조하는 것이 품질이 우수한 상품과 형성율을 높일 수 있을 것으로 기대 된다.

\section{총 폴리페놀 함량 및 항산화 활성}

건 블루베리의 항산화 특성으로 총 폴리페놀 함량과 $\mathrm{DPPH}$ radical 소거능을 측정한 결과는 Table 6에 나타내었 다. 먼저 건조 온도를 달리한 건 블루베리의 총 폴리페놀 함량을 측정한 결과 $\mathrm{A}$ 가 $13.05 \mathrm{mg} / \mathrm{GAEg}, \mathrm{B}$ 가 12.42 $\mathrm{mg} / \mathrm{GAEg}, \mathrm{C}$ 가 $11.23 \mathrm{mg} / \mathrm{GAEg}, \mathrm{D}$ 가 $9.21 \mathrm{mg} / \mathrm{GAEg}$ 로 건조 온도가 높을수록 유의적으로 낮게 나타났다 $(\mathrm{p}<0.05)$. 건조 방법에 따른 블루베리의 품질특성 연구(18)에서 $60^{\circ} \mathrm{C}$ 에서 3 일 동안 열풍 건조한 블루베리의 총 폴리페놀 함량은 10.30 $\mathrm{mg} / \mathrm{g}$ 으로 본 실험의 결과와 유사하였다. 이러한 총 페놀성 화합물들은 분자 내에 phenolic hydroxyl기를 가지고 있는 방향족 화합물로 산화 및 환원반응에서 기질로 작용한다. 블루베리에 함유되어 있는 폴리페놀류에는 chlorogenic acid, quercetin, anthocyanin, kaempferol, myricetin, catechin, resveratrol 등이 있고 이들이 항산화 활성에 관여하는 것으 로 보고되고 있다(26). Sellappan 등의 연구(27)에 의하면 베리류의 총 폴리페놀 함량을 측정한 결과 블루베리가 5.60 $\mathrm{mg} \mathrm{GAE} / \mathrm{g}$, 블랙베리가 $4.9 \mathrm{mg} \mathrm{GAE} / \mathrm{g}$ 이었다고 보고하였는 데, 본 실험의 건 블루베리가 총 폴리페놀함량이 더 높게

Table 4. Texture of dried blueberry with different drying temperatures

\begin{tabular}{ccccc}
\hline \multirow{2}{*}{ Texture } & \multicolumn{4}{c}{ Drying condition $^{\mathrm{l})}$} \\
\cline { 2 - 5 } properties & $\mathrm{A}$ & $\mathrm{B}$ & $\mathrm{C}$ & $\mathrm{D}$ \\
\hline Hardness & $3,008.00 \pm 271.53^{\mathrm{d} 2}$ & $5,793.08 \pm 362.23^{\mathrm{c}}$ & $6,569.33 \pm 399.47^{\mathrm{b}}$ & $9,797.64 \pm 412.17^{\mathrm{a}}$ \\
Springiness & $0.29 \pm 0.04$ & $0.29 \pm 0.04$ & $0.34 \pm 0.03$ & $0.34 \pm 0.02$ \\
Cohesiveness & $0.20 \pm 0.03$ & $0.28 \pm 0.03$ & $0.32 \pm 0.04$ & $0.32 \pm 0.02$ \\
Gumminess & $872.32 \pm 26.94^{\mathrm{d}}$ & $1,652.70 \pm 202.42^{\mathrm{c}}$ & $2,213.01 \pm 304.63^{\mathrm{b}}$ & $3,151.10 \pm 177.92^{\mathrm{a}}$ \\
Chewiness & $167.09 \pm 14.41^{\mathrm{d}}$ & $480.57 \pm 73.63^{\mathrm{c}}$ & $747.67 \pm 157.82^{\mathrm{b}}$ & $1,077.52 \pm 79.74^{\mathrm{a}}$ \\
\hline
\end{tabular}

${ }^{1)} \mathrm{A}, 40^{\circ} \mathrm{C}-72 \mathrm{hr} ; \mathrm{B}, 40^{\circ} \mathrm{C}-48 \mathrm{hr}$ and $50^{\circ} \mathrm{C}-24 \mathrm{hr} ; \mathrm{C}, 50^{\circ} \mathrm{C}-72 \mathrm{hr} ; \mathrm{D}, 60^{\circ} \mathrm{C}-72 \mathrm{hr}$.

${ }^{2)}$ Values are mean $\pm \mathrm{SD}(\mathrm{n}=10)$. Means with different superscripts within a column differ significantly $(\mathrm{p}<0.05)$.

Table 5. Sensory characteristics of dried blueberry with different drying temperatures

\begin{tabular}{ccccccc}
\hline \multirow{2}{*}{ Drying condition ${ }^{\mathrm{l})}$} & \multicolumn{5}{c}{ Sensory characteristics } \\
\cline { 2 - 7 } & Appearance & Color & Moisture & Texture & Taste & Overall acceptability \\
\hline A & $7.0 \pm 1.2^{22}$ & $7.0 \pm 0.9^{\mathrm{a}}$ & $6.5 \pm 0.7^{\mathrm{b}}$ & $6.6 \pm 1.0^{\mathrm{b}}$ & $7.0 \pm 1.1^{\mathrm{b}}$ & $7.1 \pm 0.8^{\mathrm{b}}$ \\
B & $6.5 \pm 1.0^{\mathrm{b}}$ & $6.7 \pm 0.5^{\mathrm{b}}$ & $6.9 \pm 1.1^{\mathrm{a}}$ & $7.0 \pm 0.7^{\mathrm{a}}$ & $7.3 \pm 1.1^{\mathrm{a}}$ & $7.6 \pm 1.0^{\mathrm{a}}$ \\
C & $5.9 \pm 1.4^{\mathrm{c}}$ & $6.1 \pm 1.4^{\mathrm{c}}$ & $6.0 \pm 1.1^{\mathrm{c}}$ & $6.0 \pm 0.9^{\mathrm{c}}$ & $5.9 \pm 1.7^{\mathrm{c}}$ & $6.0 \pm 1.1^{\mathrm{c}}$ \\
D & $4.1 \pm 1.5^{\mathrm{d}}$ & $4.6 \pm 1.3^{\mathrm{d}}$ & $3.1 \pm 1.0^{\mathrm{d}}$ & $3.9 \pm 1.4^{\mathrm{d}}$ & $3.8 \pm 1.5^{\mathrm{d}}$ & $3.6 \pm 1.0^{\mathrm{d}}$ \\
\hline
\end{tabular}

${ }^{11} \mathrm{~A}, 40^{\circ} \mathrm{C}-72 \mathrm{hr} ; \mathrm{B}, 40^{\circ} \mathrm{C}-48 \mathrm{hr}$ and $50^{\circ} \mathrm{C}-24 \mathrm{hr} ; \mathrm{C}, 50^{\circ} \mathrm{C}-72 \mathrm{hr} ; \mathrm{D}, 60^{\circ} \mathrm{C}-72 \mathrm{hr}$.

${ }^{2)}$ Values are mean $\pm S D(n=20)$. Means with different superscripts within a column differ significantly $(\mathrm{p}<0.05)$.

Table 6. Total polyphenol content and DPPH radical scavenging activity of dried blueberry with different drying temperatures

\begin{tabular}{ccc}
\hline $\begin{array}{c}\text { Drying } \\
\text { condition }^{1)}\end{array}$ & $\begin{array}{c}\text { Total polyphenol content } \\
(\mathrm{mg} / \mathrm{GAEg})\end{array}$ & $\begin{array}{c}\text { DPPH radical } \\
\text { scavenging activity }(\%)\end{array}$ \\
\hline A & $13.05 \pm 2.64^{\mathrm{a} 2)}$ & $41.32 \pm 0.82^{\mathrm{a}}$ \\
B & $12.42 \pm 0.43^{\mathrm{b}}$ & $41.01 \pm 1.03^{\mathrm{a}}$ \\
C & $11.23 \pm 2.56^{\mathrm{C}}$ & $35.25 \pm 0.95^{\mathrm{b}}$ \\
D & $9.21 \pm 1.28^{\mathrm{d}}$ & $34.80 \pm 1.37^{\mathrm{c}}$ \\
\hline
\end{tabular}

${ }^{11)} \mathrm{A}, 40^{\circ} \mathrm{C}-72 \mathrm{hr} ; \mathrm{B}, 40^{\circ} \mathrm{C}-48 \mathrm{hr}$ and $50^{\circ} \mathrm{C}-24 \mathrm{hr} ; \mathrm{C}, 50^{\circ} \mathrm{C}-72 \mathrm{hr} ; \mathrm{D}, 60^{\circ} \mathrm{C}-72 \mathrm{hr}$. ${ }^{2)}$ Values are mean $\pm \mathrm{SD}(\mathrm{n}=3)$. Means with different superscripts within a column differ significantly $(\mathrm{p}<0.05)$.
나타났다.

일반적으로 DPPH radical 소거능은 보라색을 띄는 비교 적 안정한 free radical으로서 유황아미노산과 ascorbic acid, polyhydroxy 등에 의해 전자나 수소를 받아 비가역적으로 안전한 분자를 형성하여 환원되어 탈색되는 원리를 이용하 여 측정하는 방법이 많이 이용되고 있다(28). 건조 온도에 따른 건 블루베리의 DPPH radical 소거능을 측정한 결과는 Table 6에서 보는 바와 같이 A가 $41.32 \%$ 가장 높은 활성을 보였으며 $\mathrm{D}$ 가 $34.80 \%$ 로 가장 낮은 활성을 보였다. 이와 같은 결과로 블루베리의 항산화 활성은 뛰어나며 건조온도 
가 낮을수록 항산화 활성은 높고 건조 온도가 높을수록 항산화 활성은 낮음을 알 수 있었다. 또한, 건 블루베리의 항산화 활성은 앞의 총 폴리페놀 함량이 증가할수록 DPPH radical 소거능도 증가하여 서로 상관관계에 있음을 확인할 수 있었다.

\section{요 약}

본 연구에서는 부재료를 첨가하지 않는 건 블루베리를 제조기술을 확립하고자 건조 온도를 달리하여 건 블루베리 의 품질변화와 항산화 특성을 조사하였다. 즉, 건 블루베리 제조는 건조 온도에 따라 $\mathrm{A}\left(40^{\circ} \mathrm{C}, 72\right.$ 시간 $), \mathrm{B}\left(40^{\circ} \mathrm{C}, 48\right.$ 시간 및 $50^{\circ} \mathrm{C}, 24$ 시간), $\mathrm{C}\left(50^{\circ} \mathrm{C}, 72\right.$ 시간 $), \mathrm{D}\left(60^{\circ} \mathrm{C}, 72\right.$ 시간 $)$ 로 하였 다. 건 블루베리의 수율을 측정한 결과 $17.73 ~ 31.17 \%$ 의 범 위이었으며 건조 온도가 낮을수록 유의적으로 높게 나타났 다 $(\mathrm{p}<0.05) . \mathrm{pH}$ 는 $\mathrm{A}$ 가 가장 높았으며 가용성 고형분 함량은 건조 온도가 높을수록 유의적으로 높아지는 것으로 나타났 다(p<0.05). 수분함량 및 수분활성도는 건조 온도가 높을수 록 낮아지는 경향으로 나타났다. 색도를 측정한 결과 $\mathrm{L}$ 값은 건조 온도가 낮은 $\mathrm{A}$ 가 높게 나타난 반면 $\mathrm{a}$ 값 및 $\mathrm{b}$ 값의 경우 는 건조 온도가 높은 $\mathrm{D}$ 가 높게 나타났다. 건조된 건 블루베 리의 색도는 건조 온도가 높을수록 건조는 빨리 되었지만 육안으로 보았을 때 과피의 색이 주황색으로 변하여 상품으 로 적절하지 않았다. 조직감 변화는 경도(hardness), 점성 (gumminess) 및 씹힘성(chewiness)은 건조 온도가 높을수록 높은 값을 나타내었으며 탄력성(springiness)과 응집성 (cohesiveness)은 비슷한 경향으로 건조 온도가 높을수록 약간 증가하는 경향이었지만 유의적인 차이는 없었다 $(\mathrm{p}<0.05)$. 관능적 특성에서 전반적인 기호도는 $\mathrm{B}>\mathrm{A}>$ $\mathrm{C}>\mathrm{D}$ 순으로 평가되었다. 항산화 특성으로 총 폴리페놀 함량과 DPPH radical 소거능을 측정한 결과 건조 온도가 낮을수록 항산화 활성이 높게 나타났다. 따라서 건 블루베 리 제조에 적당한 처리군은 $\mathrm{B}$ 로 열 풍건조 온도를 $40^{\circ} \mathrm{C}$ 로 하여 48 시간 건조 후 온도를 $50^{\circ} \mathrm{C}$ 로 높여 24 시간 동안 건조 하는 것이 품질이 우수한 상품과 형성율을 높이는데 좋을 것으로 생각된다.

\section{감사의 글}

본 연구는 농촌진흥청 연구사업(PJ 010919)의 지원에 의 해 이루어진 것임.

\section{References}

1. Westwood MN (1993) Temperate-zone pomology.
Timber Press, Portland, OR, USA, p 100-101

2. Zheng W, Wang SY (2003) Oxygen radical absorbing capacity of penolics in blueberries, cranberries, chokeberries, and ligonberries. J Agric Food Chem, 51, 502-509

3. Ministry for Food, Agriculture, Forestry and Fisheries (2012) Food news. Food J, p 175, p 118

4. KOSIS (2011) Korean Statistical Information Service. Agricultural Statistics Info:An output tendency of crops. Available from: http:kosis.kr/nsikor/view/ stat10.do. accessed December 30th

5. Su MS, Chien PJ (2007) Antioxidant activity, anthocyanins, and phenolics of rabbiteye blueberry (Vaccinium ashei) fluid products as affected by fermentation. Food Chem, 104, 182-187

6. Magdalini AP, Andriana D, Zacharoula IL, Paul C, Dorothy K, Marigoula M, Fotini NL (2009) Effect of a polyphenol-rich wild blueberry extract on cognitive performance of mice, brain antioxidant markers and acetylcholinesterase activity. Behavioural Brain Research, 198, 352-358

7. Lee SN, Kang KJ (2010) The effect of blueberry extract on gene expressions related to apoptosis in human breast cancer MCF7 cells. J East Asian Soc Dietary Life, 20, 30-36

8. Park SJ, Jung SH, Park JT, Kim HY, Song KB (2014) Pre-freezing treatment of blueberry, Korean raspberry, and mulberry. J Appl Biol Chem, 57, 161-164

9. Jang SI, Lee JH (2014) Radioprotective effects of blueberry on the liver of radiation irradiated rats. J Korean Soc Radiology, 7, 239-244

10. Moon HK, Lee SW, Kim JK (2013) Physicochemical and quality characteristics of the Korean and American blueberries. Korean J Food Preserv, 20, 524-531

11. Han JM, Chung HJ (2013) Quality characteristics of Yanggaeng added with blueberry powder. Korean J Food Preserv, 20, 265-271

12. Park HM, Yang SJ, Kang EJ, Lee DH, Kim DI, Hong $\mathrm{JH}$ (2012) Quality characteristics and granule manufacture of mulberry fruit extracts. Korean J Food Cookery, 28, 375-382

13. Lee WG, Lee JA (2012) Quality characteristics of yogurt dressing prepared with blueberry juice. Korean J Culinary Res, 18, 255-265

14. Jeon MH, Lee WJ (2011) Characteristics of blueberry added Makgeolli. J Korean Soc Food Sci Nutr, 40, 444-449 
15. Ji JR, Yoo SS (2010) Quality characteristics of cookies with varied concentration of blueberry powder. J East Asian Soc Dietary Life, 20, 727-734

16. Cho WJ, Song BS, Lee JY, Kim JK, Kim JH, Yoon YH, Choi JI, Kim KS, Lee JW (2010) Composition analysis various blueberry jam by response surface methodology. J Korean Soc Food Sci Nutr, 39, 319-323

17. Hong JH, Lee WY (2004) Quality characteristics of osmotic dehydrated sweet pumpkin by different drying methods. J Korean Soc Food Sci Nutr, 33, 1573-1579

18. Park SJ, Choi YB, Ko JR, Rha YA, Lee HY (2014) Effects of drying methods on the quality and physiological activities of blueberry (Vaccinium ashei). Korean J Culinary Res, 20, 55-64

19. Kim YJ, Sujin Lee SJ, Kim MY, Kim GI, Chung HS, Park HJ, Kim MO, Kwon JH (2009) Physicochemical and organoleptic qualities of sliced-dried persimmons as affected by drying methods. Korean J Food Sci Technol, 14, 64-68

20. Folin O, Denis W (1915) A colorimetric method for determination of phenols (phenol derivatives) in urine. J Bio Chem, 22, 305-308

21. Blois MS (1958) Antioxidant determinations by the use of a stable free radical. Nature, 26, 1199-1200

22. Lee SW, Moon HK, Lee WY, Kim JK (2011) Physicochemical characteristics of cold-air dried persimmons and traditional dried persimmons. Korean J Food Preserv, 18, 481-487
23. Oh HH, Hwang KT, Kim MY, Lee HK, Kim SZ (2008) Chemical characteristics of raspberry and blackberry fruits produced in Korea. J Korean Soc Food Sci Nutr, 37, 738-743

24. Yook HS, Kim KH, Jang SA (2010) Quality characteristics of grape pomace with different drying methods. J Korean Soc Food Sci Nutr, 39, 1353-1358

25. Choi HD, Lee HC, Kim YS, Choi IW, Park YK, Seog HM (2008) Effect of combined osmotic dehydration and hot-air drying on the quality of dried apple products. Korean J Food Sci Technol, 40, 36-41

26. Giovanelli G, Buratti S (2008) Comparison of polyphenolic composition and antioxidant activity of wild Italian blueberries and some cultivated varieties. Food Chem, 112, 903-908

27. Sellappan S, Akoh CC, Krewer G (2002) Phenolic compounds and antioxidant capacity of Georgia-grown blueberries and blackberries. J Agric Food Chem, 50, 2432-2438

28. Wang KJ, Zhang YJ, Yang CR (2005) Antioxidant phenolic compounds from rhizomes of Polygonum paleaceum. J Ethnopharmacol, 96, 483-487 